\title{
Effect of Potassium Humate on some Metabolic Products of Wheat Plants Grown under Saline Conditions. \\ Hanaa M. Salem ${ }^{1}$; Yossria Abo-Setta ${ }^{1}$; M. A. Aiad ${ }^{2}$; Hebat-Allah A. Hussein ${ }^{1}$ and \\ Rasha A. El-Awady ${ }^{2}$ \\ ${ }^{1}$ Bot. and Micro. Dept., Fac. of Sci. (Girls Branch) Al-Azhar Univ. \\ ${ }^{2}$ Soils, Water and Environment Res. Instit. A. R. C.
}

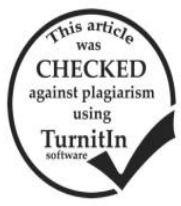

\section{ABSTRACT}

A lysimeter experiment was carried out at Agricultural Research Station, Sakha, Kafr El-Sheikh governorate, during the growth season of 2013/2014 to study the effectiveness of potassium humate on improving the tolerance of wheat plants to saline conditions and its effect on some metabolic products. Irrigation of wheat plants with diluted sea water i.e. EC 6, 9 and $12 \mathrm{dS} / \mathrm{m}$ decreased chlorophyll a, chlorophyll b \& carotenoids contents and total protein contents but increased total carbohydrate and proline contents. Soil addition of potassium humate at $(4 \& 8 \mathrm{~kg} /$ feddan) increased the metabolic products of wheat plants under unsalinized conditions; the low rate of potassium humate gave better increments than the higher one. Additionally, this material ameliorated the depressive effect of salinity on wheat plants.

Keywords: wheat plants - salinity, potassium humate.

\section{INTRODUCTION}

Soil salinity has become a serious environmental problem which affects the growth and productivity of many crops. High salt content in the soil affects the soil porosity and also decreases soil water potential that results in a physiological drought (Afzal et al., 2012). High salt content also, affects the physiology of plants, both at the cellular as well as whole plant levels (Radi et al., 2013). Salt stress causes membrane damage, nutrient imbalance, altered levels of growth regulators, enzymatic inhibition and metabolic dysfunction, including photosynthesis which ultimately leads to plant death (Aasanuzzaman et al., 2012). Adaptation of plants against salt stress is marked by the accumulation of compatible solutes. These compounds have the ability to regulate the physiology and biochemical process.

Wheat (Triticum aestivum L.) occupied second place in production at global level. It contributes towards food front to the tune of 36 percent of the world population and provides 20 percent of total global calorie supply. Bread of wheat is the main food of people in many countries and 80 percent protein of human is supplied from its consumption. Therefore, considering increasing country and world population and current shortage of food worldwide, evaluation of methods and strategies which lead to increase production and optimal use of produced wheat is one of the important and significant issues (Siahoosh and Dehanianb, 2011).

Humic acid (HA) could be used as one of the main organic fertilizers, which is an important component of humic substances. Potassium humate is the salt of humic acid (Patil et al., 2010). Humic acids are the most significant constituents of organic matter in both soils and municipal waste compost, and have a relevant role in the cycling of many elements in the environment and in soil ecological functions (Senesi et al., 1996). The direct and indirect beneficial effects of HA on plant growth and development are related to its effect on cell membranes which lead to the enhanced transport of minerals, improved protein synthesis, plant hormone-like activity, promoted photosynthesis, modified enzyme activities, solubility of micro-elements and macro-elements, reduction of active levels of toxic minerals and increased microbial populations (Hamideh et al., 2013). Furthermore, Humic acid counteracted the adverse effect of salinity by increasing nutrient uptake and reduction of toxic metal intake from soil solution (Asik et al., 2009; Masciandaro et al., 2002). The humic acid significantly increased some metabolic products of plants i.e. photosynthetic pigments, total soluble sugars, total carbohydrates, total amino acids and proline (Safwat et al., 2014). These positive influences of humic acid on plant growth could be mainly due to hormone-like activities of the humic acids through their involvement in cell respiration, photosynthesis, oxidative phosphorelation, protein synthesis and various enzymatic reactions (Chen and Aviad, 1990).

The aim of the current study is to investigate the effect of potassium humate on alleviating the adverse and hurt effect of sea water salinity and improving some metabolic products (photosynthetic pigments, total carbohydrate \& protein contents and proline content) of wheat plants.

\section{MATERIALS AND METHODS}

A lysimeter experiment was carried out during (2013- 2014) growth season at the experimental station of Agricultural Research, Sakha, Kafr-El Sheikh. The experiment was conducted in split plot design; the lysimeter area was $\left(1 \mathrm{~m}^{2}\right)$. The lysimeters were filled with clay soil and irrigated with tap water until complete germination. Saline solution at the EC concentrations 6,9 and $12 \mathrm{dS} / \mathrm{m}$ were prepared from Mediterranean Sea water near Baltim and tap water was used for dilution. The physical and chemical properties of the soil are presented in Table (1).

Table 1. Physical and chemical properties of the soil used. Particle size distribution Chemical properties

\begin{tabular}{|c|c|c|c|c|c|c|c|c|c|c|c|c|c|}
\hline \multirow{2}{*}{ Sand\% } & \multirow[b]{2}{*}{ Silt \% } & \multirow{2}{*}{ Clay\% } & \multirow{2}{*}{ Texture } & \multirow{2}{*}{$\mathbf{P H}^{*}$} & \multirow{2}{*}{$\begin{array}{l}\text { EC } \\
\text { dS/m }\end{array}$} & \multicolumn{4}{|c|}{ Cations, $\mathrm{meq} / \mathrm{L}$} & \multicolumn{4}{|c|}{ Anions, meq/L } \\
\hline & & & & & & $\mathbf{M g}^{++}$ & $\mathbf{C a}^{++}$ & $\mathbf{K}^{+}$ & $\mathrm{Na}^{+}$ & $\mathrm{CO}_{3}{ }^{-2}$ & $\mathrm{HCO}_{3}^{-}$ & $\mathrm{Cl}^{-}$ & $\mathrm{SO}_{4}^{-2}$ \\
\hline 16.56 & 31.26 & 52.18 & Clay & 8.23 & 3.76 & 4.9 & 7.5 & 0.8 & 26.7 & -- & 3.5 & 19.7 & 16.7 \\
\hline
\end{tabular}


The grains of wheat plants (Triticum aestivum, cv. sakha 93) obtained from the Department of Cereal Research, Agricultural Research Station, Sakha, Kafr-El Sheikh. Grains of wheat cultivar were planted on $15^{\text {th }}$ November in 2013 at equal distance and depth from the soil surface. Soil was prepared before sowing and fertilized with NPK at $75 \mathrm{~kg} \mathrm{~N} /$ Feddan as urea, $100 \mathrm{~kg}$ $\mathrm{P}_{2} \mathrm{O}_{5}$ / Feddan which added in the form of calcium superphosphate $\left(15.5 \% \mathrm{P}_{2} \mathrm{O}_{5}\right)$ and $50 \mathrm{~kg} \mathrm{~K}_{2} \mathrm{O} /$ Feddan in the form of potassium sulphate $(48 \%$ K2O). Superphosphate and potassium sulphate were added in one dose before planting, whereas, nitrogen was added at two equal intervals, the first one before the post planting irrigation and the second dose at the tillering stage (before the second irrigation).

Mediterranean Sea water analysis is shown in Table (2) as determined in Agricultural Research Station, Sakha.

Table 2. Chemical analysis of the sea water used.

\begin{tabular}{|c|c|c|c|c|c|c|c|c|c|c|}
\hline \multirow{3}{*}{$\begin{array}{l}\text { Analysis of } \\
\text { Sea water }\end{array}$} & \multirow{3}{*}{$\frac{\mathbf{p H}}{7.43}$} & \multirow{3}{*}{$\begin{array}{c}\begin{array}{c}\mathbf{E C}, \\
\mathbf{d S} / \mathbf{m}\end{array} \\
54.50\end{array}$} & \multicolumn{8}{|c|}{ Cations and anions, $\mathrm{meq} / \mathrm{L}$} \\
\hline & & & $\mathrm{Ca}^{++}$ & $\mathbf{M g}^{++}$ & $\mathrm{Na}^{+}$ & $\mathbf{K}^{+}$ & $\mathrm{CO}_{3}^{-2}$ & $\mathrm{HCO}_{3}^{-}$ & $\mathrm{Cl}^{-}$ & $\mathrm{SO}_{4}^{--}$ \\
\hline & & & 75.50 & 147.36 & 315.14 & 10.0 & -- & 39.75 & 398.0 & 110.25 \\
\hline
\end{tabular}

$\overline{\mathbf{E C}}=$ electrical conductivity.

Potassium humate at rates of (4 and $8 \mathrm{~kg} /$ feddan) were dissolved in distilled water and were added to soil before planting. K-humate application was done either alone or with sea water at different dilution levels.

Soil samples were air-dried and ground to pass through a $2 \mathrm{~mm}$ sieve. The different determinations of soil chemical and physical properties were carried out as follows: particle size distribution of the sample was determined according to the international method (Piper, 1950). Soil acidity $(\mathrm{pH})$ values were measured in the soil water suspensions (1:2.5). Cations, anions and total soluble salts were estimated in the 1:5 saturated soil water extract. Plant samples were dried at $70{ }^{\circ} \mathrm{C}$ and then weighted. Apart of the dried samples were wet digested according to chapman and Pratt (1961). Sodium and potassium was estimated by using the flame photometer. Calcium and magnesium were determined by using the versene method according to Jackson (1967). Chloride was determined by titration with silver nitrate and sulphate was determined by subtracting anions from total cations while, total nitrogen was determined by using the micro kjeldhal procedure.

At the studied season, plant samples were collected randomly from the three replicates to study some biochemical constituents of wheat plants including: (chlorophyll a, chlorophyll b, carotenoids, total carbohydrate contents, total protein contents and proline content) after 45 days (vegetative stage), 65 days (heading stage) and 90 days (anthesis stage) from sowing.

\section{Photosynthetic pigments:}

The photosynthetic pigments (chlorophyll 'a ', chlorophyll 'b ' and carotenoids) were calorimetrically determined according to Metzner et al. (1965) at the tillering and heading stages.

The concentration of the pigment fractions (chlorophyll 'a', chlorophyll 'b' and carotenoids) was measured as $\mu \mathrm{g} / \mathrm{ml}$ using the following equations:

Chlorophyll $\mathrm{a}=10.3 \mathrm{E}_{663}-0.918 \mathrm{E}_{644}=\mu \mathrm{g} / \mathrm{ml}$.

Chlorophyll $\mathrm{b}=19.7 \mathrm{E}_{644}-3.870 \mathrm{E}_{663}=\mu \mathrm{g} / \mathrm{ml}$.

Carotenoids $=4.2 \mathrm{E}_{452.5}-(0.0264$ chlorophyll $\mathrm{a}+0.426$ chlorophyll b) $=\mu \mathrm{g} / \mathrm{ml}$.

\section{Total carbohydrate contents:}

Carbohydrate content was determined in plant shoots according to Naguib (1962). The carbohydrate content (gm/ 100 gm dry wt) was determined from a standard curve using glucose sugar. Blank were prepared using $1 \mathrm{ml}$ of water instead of diluted filtrate sugar solution.

\section{Determination of total contents of protein:}

The total nitrogen content was estimated in plant shoots by modified micro-kjeldahel method as described by Paech and Tracey (1956). The protein contents were determined by multiplying the nitrogen 5.7 according to Allen (1989). The results were expressed as (g/ $100 \mathrm{~g}$ dry wt).

\section{Determination of proline content:}

Proline was determined in plant samples according to Bates et al. (1973). The proline concentration was determined by a standard, and method calculated on a dry weight basis as (mg/g dry wt).

\section{Statistical analysis}

The obtained results were statistically analyzed using the least significant differences (LSD) at $0.05 \%$ level of probability (Cochran and Cox, 1960).

\section{RESULTS AND DISCUSSION}

\section{Photosynthetic pigments:}

Results presented in Table (3) show the effect of different concentrations of diluted sea water salinity on photosynthetic pigments including chlorophyll 'a', chlorophyll ' $b$ ' and carotenoids in the leaves of wheat plants at two stages of growth; 45 days and 65 days after sowing. Data show a significant and progressive reduction in chlorophyll 'a', chlorophyll 'b' and carotenoids contents with increasing salinity concentrations, especially at high salinity concentration $(\mathrm{EC} 12 \mathrm{dS} / \mathrm{m})$. These results were true during two studied stages of wheat plants. Similar effects of salinity upon photosynthetic pigments were reported by Abbasi et al. (2015b) on maize plant and Ben Abdallah et al. (2016) on Solanum nigrum. In addition, reduction in chlorophyll concentrations is probably due to the inhibitory effect of the accumulated toxic ions on the biosynthesis of the different chlorophyll fractions in Hibiscus sabdariffa (Ali et al., 2012).

Concerning the effect of application of K-humate on photosynthetic pigments, results in Table (3) show that K-humate application increased chlorophyll a, chlorophyll $\mathrm{b}$ and carotenoids contents in leaves of wheat plants at two stages of growth compared to control. Also, K-humate treatments improved photosynthetic pigments for plants grown under diluted sea water concentrations. Addition of (4 \& $8 \mathrm{~kg} /$ feddan) K-humate caused an increment in 
chlorophyll a, chlorophyll $\mathrm{b}$ and carotenoids contents for plants grown under all salinity levels moreover, the high level of K-humate treatments seemed to be the best one for improving photosynthetic pigments under saline conditions. Thus, it could be suggested that soil addition of K-humate markedly improved chlorophyll a, chlorophyll b and carotenoids contents of wheat plants irrigated with diluted sea water at two tested stages during the studied season. Cimrin et al. (2010) found that the external supply of humic acid on salt stressed plants caused a maximum increase in all chlorophyll contents of pepper plants. This increment of photosynthetic pigments as a result of spraying plant with humic acid may be due to the role of humic acid as growth regulator which promots of plant development processes.

Table 3. Effect of salinity, potassium humate and their interaction on photosynthetic pigments $(\mathrm{mg} / \mathrm{g} \mathrm{fw})$ in leaves of wheat plants at two different growth stages.

\begin{tabular}{|c|c|c|c|c|c|c|}
\hline \multirow{2}{*}{$\begin{array}{l}\text { Parameters } \\
\text { Treatments }\end{array}$} & \multicolumn{4}{|c|}{$\begin{array}{c}\text { Chlorophyll a Chlorophyll b } \\
\text { (mg/g fw) }\end{array}$} & \multicolumn{2}{|c|}{$\begin{array}{c}\text { Carotenoids } \\
(\mathrm{mg} / \mathrm{g} \text { fw })\end{array}$} \\
\hline & $\begin{array}{c}45 \\
\text { days }\end{array}$ & $\begin{array}{l}65 \\
\text { days }\end{array}$ & $\begin{array}{c}45 \\
\text { days }\end{array}$ & $\begin{array}{l}65 \\
\text { days }\end{array}$ & $\begin{array}{c}45 \\
\text { days }\end{array}$ & $\begin{array}{c}65 \\
\text { days }\end{array}$ \\
\hline $\mathrm{S}_{0}$ & 0.90 & 2.48 & 0.53 & 0.91 & 0.15 & 0.25 \\
\hline $\mathrm{S}_{1}$ & 0.80 & 2.22 & 0.49 & 0.84 & 0.14 & 0.23 \\
\hline $\mathrm{S}_{2}$ & 0.73 & 2.05 & 0.42 & 0.73 & 0.11 & 0.18 \\
\hline $\mathrm{S}_{3}$ & 0.68 & 1.57 & 0.37 & 0.67 & 0.10 & 0.16 \\
\hline $\mathrm{Kh}_{1}+\mathrm{S}_{0}$ & 0.92 & 2.58 & 0.62 & 0.966 & 0.17 & 0.30 \\
\hline $\mathrm{Kh}_{2+} \mathrm{S}_{0}$ & 0.96 & 2.56 & 0.61 & 0.994 & 0.18 & 0.30 \\
\hline $\mathrm{Kh}_{1}+\mathrm{S}_{1}$ & 0.89 & 2.44 & 0.61 & 0.95 & 0.15 & 0.29 \\
\hline $\mathrm{Kh}_{1}+\mathrm{S}_{2}$ & 0.79 & 2.17 & 0.51 & 0.78 & 0.13 & 0.24 \\
\hline $\mathrm{Kh}_{1}+\mathrm{S}_{3}$ & 0.72 & 1.66 & 0.49 & 0.73 & 0.12 & 0.23 \\
\hline $\mathrm{Kh}_{2}+\mathrm{S}_{1}$ & 0.84 & 2.24 & 0.55 & 0.85 & 0.14 & 0.26 \\
\hline $\mathrm{Kh}_{2}+\mathrm{S}_{2}$ & 0.83 & 2.24 & 0.54 & 0.81 & 0.14 & 0.25 \\
\hline $\mathrm{Kh}_{2}+\mathrm{S}_{3}$ & 0.77 & 1.81 & 0.51 & 0.79 & 0.13 & 0.25 \\
\hline LSD at $5 \%$ & 0.018 & 0.026 & 0.003 & 0.008 & 0.002 & 0.003 \\
\hline
\end{tabular}

$S_{0}=$ Control. $S_{1}=$ EC $6 \mathrm{dS} / \mathrm{m}$. $S_{2}=$ EC $9 \mathrm{dS} / \mathrm{m} . S_{3}=$ EC $12 \mathrm{dS} / \mathrm{m}$.

$\mathrm{Kh}_{1}=4 \mathrm{~kg} /$ feddan potassium humate.

$\mathrm{Kh}_{2}=8 \mathrm{~kg} /$ feddan potassium humate.

\section{Total carbohydrate contents:}

Total carbohydrate contents in shoot system of wheat plants were significantly increased with increasing salinity concentrations in growth medium at three studied stages; 45, 65 and 90 days (Table 4). The increment in total carbohydrate contents was directly proportional to the concentrations of salinity. This increment in total carbohydrate contents due to saline conditions might be in turn playing an important role in increasing the osmotic pressure of the cytoplasm (Arulbalchandran et al., 2009). Similar effects of salinity upon total carbohydrate contents were reported by Ghogdi et al. (2012) in wheat plants and Shahid et al. (2014b) on Pisum sativum. The application of K-humate treatments in soils caused an increment in total carbohydrate contents of wheat plants compared to untreated plants. These results were obvious during the different growth stages. The low rate of K-humate treatments gave the best results for increasing total carbohydrate contents in plants. Interestingly, results in Table (4) illustrate that soil application of K-humate treatments (4 \& $8 \mathrm{~kg} /$ feddan) significantly increased the total carbohydrate contents in shoot system of plants grown under different saline conditions during the experimental period.
Table 4. Effect of salinity, potassium humate and their interaction on total carbohydrate and protein contents $(\mathrm{g} / \mathbf{1 0 0} \mathrm{g}$ dry wt) in shoots of wheat plants at different growth stages.

\begin{tabular}{lcccccc}
\hline Parameters & \multicolumn{2}{c}{$\begin{array}{c}\text { Total carbohydrate } \\
\text { contents }\end{array}$} & \multicolumn{3}{c}{ Total protein } \\
contents & $(\%)$ \\
\cline { 2 - 7 } Treatments & $\begin{array}{c}\mathbf{4 5} \\
\text { days }\end{array}$ & $\begin{array}{c}\mathbf{6 5} \\
\text { days }\end{array}$ & $\begin{array}{c}\mathbf{9 0} \\
\text { days }\end{array}$ & $\begin{array}{c}\mathbf{4 5} \\
\text { days }\end{array}$ & $\begin{array}{c}\mathbf{6 5} \\
\text { days }\end{array}$ & $\begin{array}{c}\mathbf{9 0} \\
\text { days }\end{array}$ \\
& 40.00 & 46.75 & 64.00 & 11.1 & 12.70 & 11.0 \\
$\mathrm{~S}_{0}$ & 48.58 & 64.17 & 68.13 & 9.10 & 10.2 & 9.50 \\
$\mathrm{~S}_{1}$ & 65.25 & 76.00 & 79.00 & 8.23 & 8.63 & 6.54 \\
$\mathrm{~S}_{2}$ & 68.00 & 79.00 & 81.50 & 6.84 & 7.25 & 6.05 \\
$\mathrm{~S}_{3}$ & 65.72 & 74.78 & 78.55 & 11.59 & 12.94 & 11.24 \\
$\mathrm{Kh}_{1} \mathrm{~S}_{0}$ & 63.09 & 72.68 & 77.22 & 11.58 & 12.90 & 11.13 \\
$\mathrm{Kh}_{2}+\mathrm{S}_{0}$ & 65.25 & 72.75 & 75.50 & 11.8 & 12.4 & 11.4 \\
$\mathrm{Kh}_{1}+\mathrm{S}_{1}$ & 68.50 & 81.00 & 82.83 & 8.75 & 9.13 & 7.25 \\
$\mathrm{Kh}_{1}+\mathrm{S}_{2}$ & 77.83 & 84.50 & 87.15 & 7.13 & 7.94 & 7.10 \\
$\mathrm{Kh}_{1}+\mathrm{S}_{3}$ & 59.50 & 69.33 & 71.5 & 11.0 & 11.3 & 10.7 \\
$\mathrm{Kh}_{2}+\mathrm{S}_{1}$ & 66.00 & 79.50 & 81.00 & 9.46 & 10.0 & 8.96 \\
$\mathrm{Kh}_{2}+\mathrm{S}_{2}$ & 75.17 & 82.83 & 85.50 & 7.75 & 8.92 & 7.62 \\
$\mathrm{Kh}_{2}+\mathrm{S}_{3}$ & 1.17 & 0.88 & 0.76 & 0.36 & 0.32 & 0.24 \\
$\mathrm{LSD}_{2}$ at $5 \%$ & 1.17 &
\end{tabular}

$S_{0}=$ Control. $S_{1}=$ EC $6 \mathrm{dS} / \mathrm{m}$. $S_{2}=$ EC $9 \mathrm{dS} / \mathrm{m} . S_{3}=$ EC $12 \mathrm{dS} / \mathrm{m}$. $\mathrm{Kh}_{1}=4 \mathrm{~kg} /$ feddan potassium humate. $\mathrm{Kh}_{2}=8 \mathrm{~kg} /$ feddan potassium humate.

The low level of K-humate treatments seemed to be the best one for improving total carbohydrate contents under saline conditions at the three growth stages during the growth season.

\section{Total protein contents:}

The results in (Table 4) reveal that total protein content in shoot of wheat plants was significantly decreased with increasing diluted sea water concentrations. This depression in total protein content was true for three growth stages during the studied season. Salinity caused a degradation of protein in various plant parts by stimulating protease activity of wheat plants (Aldesuquy et al., 2012). Similar results were also reported by Oosterhuis et al. (2013) on cotton plants and Muneer and Jeong (2015) on tomato plants.

The results declared a pronounced increment was achieved in total protein contents of wheat plants under controlled conditions and treated with K-humate at ( 4 \& $8 \mathrm{~kg} /$ feddan) as pretreated in soil. This was more obvious when the low rate of K-humate was used. Additionally, using K-humate increased protein contents in shoot of wheat plants grown under saline conditions compared to untreated salinized conditions.

The high level of K-humate seemed to be the best one for improving total protein contents for plants grown under saline conditions. Natural humic acids can be used an ecological alternative to increase tolerance of plants to drought, because they have been shown to stimulate protein synthesis and its activity (Muscolo et al., 2007). Humic acids play this role through a phytohormonal mechanism and many studies have found that it can dramatically stimulate $\mathrm{H}^{+}$ATPase in plants (Dobbs et al., 2010).

\section{Proline content:}

Under saline conditions, results in Table (5) declare that proline content in shoot of wheat plants was significantly increased as a result of salinity treatments in the three stages during the growing season. Similar results were reported by Shahid et al. (2014a) on Pisum sativum and Bazzar and Hossain (2015) on soybean 
plant. Additionally, Proline accumulation under water stress facilitates the permanent synthesis of soluble substances in closing stomata which reduce losing of water (Ghorbanli et al., 2013).

Proline content was significantly increased by applying K-humate compared to control value. This increment was more obvious at low rate of K-humate. Moreover, proline content was significantly increased in plants treated with K-humate at the three stages. Proline is known to be involved in osmoregulation, acts as free radical scavenger (Yildiz and Terzi, 2013) and is typically elevated by $\mathrm{NaCl}$ in various species such as barley cultivars (Haddadi et al., 2016).

Table 5. Effect of salinity, potassium humate and their interactions on proline content $(\mathrm{mg} /$ g dry wt) in shoots of wheat plants at different growth stages.

\begin{tabular}{|c|c|c|c|}
\hline \multirow{2}{*}{$\begin{array}{l}\text { Parameter } \\
\text { Treatments }\end{array}$} & \multicolumn{3}{|c|}{ Proline content (mg/g dry wt) } \\
\hline & 45 days & 65 days & 90 days \\
\hline $\mathrm{S}_{0}$ & 0.60 & 0.66 & 0.99 \\
\hline $\mathrm{S}_{1}$ & 0.69 & 0.78 & 1.04 \\
\hline $\mathrm{S}_{2}$ & 0.79 & 094 & 1.56 \\
\hline $\mathrm{S}_{3}$ & 0.86 & 1.18 & 1.92 \\
\hline $\mathrm{Kh}_{1}+\mathrm{S}_{0}$ & 1.44 & 1.78 & 2.24 \\
\hline $\mathrm{Kh}_{2}+\mathrm{S}_{0}$ & 1.22 & 1.50 & 1.81 \\
\hline $\mathrm{Kh}_{1}+\mathrm{S}_{1}$ & 1.01 & 1.82 & 2.24 \\
\hline $\mathrm{Kh}_{1}+\mathrm{S}_{2}$ & 1.18 & 1.89 & 2.37 \\
\hline $\mathrm{Kh}_{1}+\mathrm{S}_{3}$ & 2.04 & 2.08 & 2.79 \\
\hline $\mathrm{Kh}_{2}+\mathrm{S}_{1}$ & 0.79 & 1.31 & 1.63 \\
\hline $\mathrm{Kh}_{2}+\mathrm{S}_{2}$ & 0.81 & 1.34 & 1.85 \\
\hline $\mathrm{Kh}_{2}+\mathrm{S}_{3}$ & 1.01 & 1.48 & 1.96 \\
\hline LSD at $5 \%$ & 0.04 & 0.02 & 0.04 \\
\hline
\end{tabular}

\section{REFERENCES}

Aasanuzzaman, M.; M. A. Hossain and M. Fujita (2012). Exogenous selenium pretreatment protects rapeseed seedlings from cadmium-induced oxidative stress by up regulating the antioxidant defense and methyl glyoxalin detoxification systems. Biological Trace Element Research, 149: 246- 261.

Abbasi, G. H.; J. Akhtar; M. Anwar-ul-Haq; W. Malik; S. Ali; Z. Chen and G. Zhang (2015b). Morphophysiological and micrographic characterization of maize hybrids under $\mathrm{NaCl}$ and cd stress. Plant Growth Regul, 75: 115- 122.

Abd El Baky. (2009). Enhancing antioxidant availability in grains of wheat plants grown under seawater stress in response to microalgea extract treatments. Afr. J. Biochem. Res., 3: 77- 83.

Afzal, I.; A. Butt; H. U. Rehman; S. Basra and A. Afzal (2012). Alleviation of salt stress in fine aromatic rice by seed priming. Australian J . Crop Sci., 6: 1401- 1407 .

Aldesuquy, H. S.; A. S. A. Hamed; M. A. Abbas and A. H. ElHakem (2012). Role of glycine betaine and salicylic acid in improvin growth vigour and physiological aspects of droughted wheat cultivars. J. Stress Physiol Biochem., 8: 149171.

Ali, H. M.; M. H. Siddiqui; M. O. Basalah; M. H. AlWhaibi; A. M. Sakran and A. Al-Amri (2012). Effects of gibberellic acid on growth and photosynthetic pigments of Hibiscus sabdariffa L. under salt stress. African Journal of Biotechnology, 11: 800- 804.

Allen, S. E. (1989). Chemical Analysis of Ecological Materials. Blackwell scientific publications. Oxford, London, Edinburgh, pp. 368.

Arulbalchandran, D.; K. S. Ganesh and A. Subramani (2009). Changes in metabolities and antioxidant enzyme activity of three Vigna species induced by $\mathrm{NaCl}$ stress. American Eurasian Journal of Agronomy, 2 (2): 109- 116.

Asik, B. B.; M. A. Turan; H. Celik and A. V. Katkat (2009). Effects of Humic Substances on Plant Growth and Mineral Nutrients Uptake of Wheat (Triticum durum cv. Salihli) Under Conditions of Salinity, Asian Journal of Crop Science, vol. 1, No. 2, pp. 87- 95.

Bates, L. S.; R. P. Waldrem and L. D. Tear (1973). Rapid determination of praline for water stress studies. Plant and Soil, 39: 205- 207.

Bazzar, M. M. and M. A. Hossain (2015). Plant water relations and proline accumulations in soybean under salt and water stress environment. Journal Plant Science, 3: 272- 278.

Ben Abdallah, S.; B. Aung; L. Amyot; I. Lalin; M. Lachaal; N. Karray-Bouraoui and A. Hannoufa (2016). Salt stress $(\mathrm{NaCl})$ affects plant growth and branch pathways of carotenoids and flavonoid biosynthesis in Solanum nigrum. Actaphysiol plant, 38: article no. 72.

Chapman, H. D. and P. F. Pratt (1961). Methods of Analysis for Soils, Plants and Waters. Division of Agricultural Sciences, University of California, pp. 56- 64.

Chen, Y. and T. Aviad (1990). Effect of Humic Substances on Plant Growth. In: Humic Substances in Soil and Crop Sciences: Selected Reading, MacCarthy, P., C.E. Clapp, R.L. Malcolm and P.R. Bloom (Eds). Soil Science Society Am., Madison, WI., pp: 161187.

Cimrin, K. M.; Ö. Türkmen; M. Turan and B. Tuncer (2010). Phosphorus and humic acid application alleviate salinity stress of pepper seedling. Afr. J. Biotechnol., 9: 5845- 5851.

Cochran, W. G. and G. M. Cox (1960). "Experimental Designs", $2^{\text {nd }}$ ed. John Welly, New York.

Dobbs, L.; L. P. Canellas; F. L. Olivares; N. O. Aguiar; L. E. P. Peres; R. Spaccini and A. Piccolo (2010). Bioactivity of chemically transformed humic matter from vermicompost on plant root growth. Journal Agriculture Food Chem., 127: 1- 10.

Ghogdi, E. A.; A. Lzadi-Darbandi and A. Borzouei (2012). Effect of salinity on some physiological traits in wheat (Triticum aestivum L.) cultivars. Indian journal of Science and Technology, 5: 1901- 1906. 
Ghorbanli, M.; M. Gafarabad; T. Amirkian and B. A. Mamaghani (2013). Investigation of proline, total protein, chlorophyll, ascorbate and dehydroascorbate changes under drought stress in Akria and Mobil tomato cultivars. Iranian Journal of Plant Physiology, 3: 651- 658.

Haddadi, B. S.; H. Hassanpour and V. Niknam (2016). Effect of salinity and waterlogging on growth, anatomical and antioxidative responses in Mentha aquatica L. Acta Physiol Plants, 38: article, no. 119.

Hamideh, G. S.; Z. O. Samavat2 and Ardebili (2013). The alleviating effects of humic substances on photosynthesis and yield of Plantago ovate in salinity conditions, International Research Journal of Applied and Basic Sciences, vol. 4, No. 7, pp. 1683- 1686.

Humic substances to reduce salt effect on plant germination and growth. Common. Soil Sci. Plant Anal., 33: 365- 378.

Jackson, M. L. (1967). Soil Chemical Analysis. Prentice Hall of India, New Delhi.

Masciandaro, G.; B. Ceccanti; V. Ronchi; S. Benedicto and L. Howard (2002).

Metzner, H.; H. Rau and H. Senger (1965). Untersuchungen Zur Sychno-nisier- Barkeit einzelner Pigment Mangel Mutanten Von. Chlorella, Planta, 65: 186.

Muneer, S. and B. R. Jeong (2015). Proteomic analysis of salt-stress responsive proteins in roots of tomato (Lycopersicon esculentum L.) plants towards silicon efficiency. Plant Growth Regul., 77: 1 - 14.

Muscolo, A.; M. Sidari; E. Attiná; O. Francois; V. Tugnoli and S. Nardi (2007). Biological activity of humic substances is related to their chemical structure. Soil Science Soc. Am. J., 71: 75- 85.

Naguib, M. I. (1962). Arapid colorimetric procedure for the estimation of free and conjugated sugars in plant extracts. Zucker, 15: 351.

Oosterhuis, D. M.; D. A. Loka and T. B. Raper (2013). Potassium and stress alleviation: physiological functions and management of cotton. J. Plant Nutrition Soil Science, 176: 331- 343.

Paech, K. and M. V. Tracey (1956). Modern Methods of Plant Analysis. Vol. 1. Springer-Verlag, Berlin, 4: 643 .
Patil, R. B.; S. S. Mokle and S. S. Wadje (2010). Effect of potassium humate on seed germination, seedling growth and vegetative characters of Triticum aestivum (L.) cv. Lokvan. International Journal of Pharma and Bio Sciences, V. 1 (1).

Piper, C. S. (1950). Soil and Plant Analysis. Inter. Sci. Publishers Inc. New York.

Radi, A. A.; F. A. Farghaly and A. M. Hamada (2013). Physiological and biochemical responses of salttolerant and salt-sensitive wheat and bean cultivars to salinity. J. Bil. Earth Science, 3: B73B88.

Safwat, H. M.; A. B. Bakry; A. A. Amany and M. A. Maha (2014). Physiological Role of Humic Acid and Nicotinamide on Improving Plant Growth, Yield, and Mineral Nutrient of Wheat (Triticum durum) Grown under Newly Reclaimed Sandy Soil. Agricultural Sciences, 5: 687- 700.

Senesi, N.; T. M. Miano and G. Brunetti (1996). HumicLike Substances in Organic Amendments and Effects on Native Soil Humic Substances. In: Piccolo, A., Ed., Humic Substances in Terrestrial Ecosystems, Elsevier, New York, 531- 593.

Shahid, M. A.; R. M. Balal; M. A. Perez; T. Abbas; M. A. Aqueel; M. M. Javaid and F. Garcia-Sanchez (2014a). Exogenous proline and proline enriched Lolium perenne leaf extract protects from phytotoxicity effects of nickel and salinity in Pisum sativum by altering polyamine metabolism in leaves. Turk J. Botany.

Shahid, M. A.; R. M. Balal; M. A. Rervez; F. GarciaSanchez; V. Gimeno; T. Abbas; N. S. Mattson and A. Riaz (2014b). Treatment with 24epibrassinolide mitigates $\mathrm{NaCl}$-induced toxicity by enhancing carbohydrate metabolism, osmolyte accumulation, and antioxidant activity in Pisum sativum. Turk J. Botany, 38: 511- 525.

Siahoosh, M. R. and E. Dehanianb (2011). Water use effeciciency transpiration efficiency and uptake efficiency of wheat during drought. Agron. J., 104: 1238- 1243.

Yildiz, M. and H. Terzi (2013). Effect of $\mathrm{NaCl}$ stress on chlorophyll biosynthesis, proline, lipid peroxidation and antioxidative enzymes in leaves of salt-tolerant and salt-sensitive barley cultivars. J. Agric. Sci., 19: 79- 88.

\footnotetext{
تاثير هيومات البوتاسيوم على بعض النواتج الايضية لتباتات القمح النامية تحث الظروف الملحية.

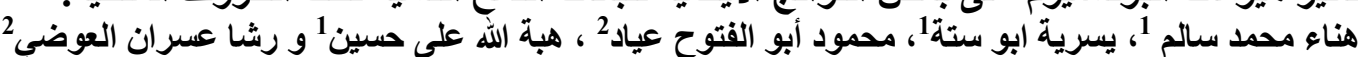

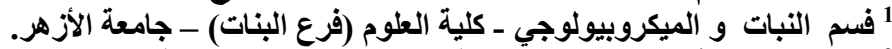

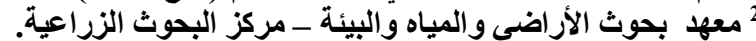

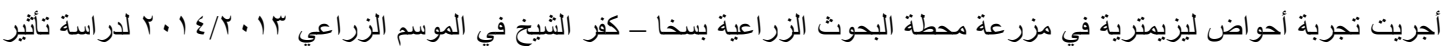

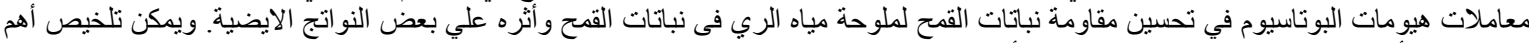

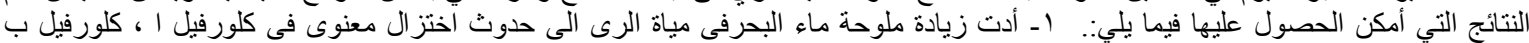

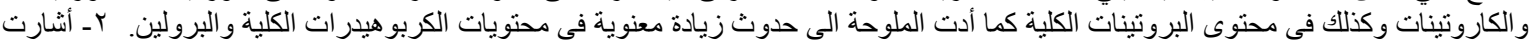

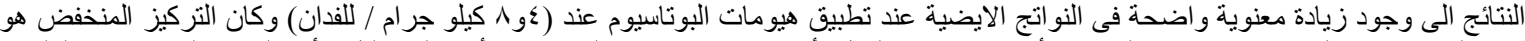

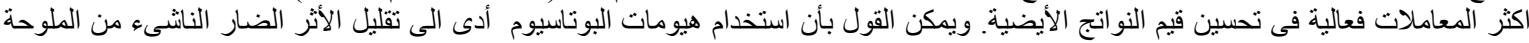

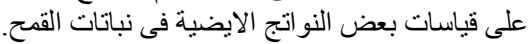

